\title{
Immunotherapy for Uterine Cervical Cancer
}

\author{
Masahiro Kagabu*, Takayuki Nagasawa, Daisuke Fukagawa, Hidetoshi Tomabechi, Seiya Sato, \\ Tadahiro Shoji ${ }^{(D)}$ and Tsukasa Baba \\ Department of Obstetrics and Gynecology, Iwate Medical University School of Medicine, Morioka, \\ Iwate 020-8505, Japan; tnagasaw@iwate-med.ac.jp (T.N.); dfukaga@yahoo.co.jp (D.F.); \\ bechitomabehi@gmail.com (H.T.); sseiya@iwate-med.ac.jp (S.S.); tshoji@iwate-med.ac.jp (T.S.); \\ babatsu@iwate-med.ac.jp (T.B.) \\ * Correspondence: mkagabu@iwate-med.ac.jp; Tel.: +81-19-651-5111
}

Received: 28 July 2019; Accepted: 10 September 2019; Published: 17 September 2019

\begin{abstract}
Cervical cancer is a malignant neoplastic disease that is the fourth most commonly occurring cancer in women worldwide. Since the introduction of angiogenesis inhibitors, treatments for recurrent and advanced cervical cancers have improved significantly in the past five years. However, the median overall survival in advanced cervical cancer is 16.8 months, with a 5-year overall survival rate of $68 \%$ for all stages, indicating that the effects of the treatment are still unsatisfactory. The development of a new treatment method is therefore imperative. Recently, in the clinical oncology field, remarkable progress has been made in immunotherapy. Immunotherapy is already established as standard therapy in some fields and in some types of cancers, and its clinical role in all areas, including the gynecology field, will change further based on the outcomes of currently ongoing clinical trials. This manuscript summarizes the results from previous clinical trials in cervical cancer and describes the ongoing clinical trials, as well as future directions.
\end{abstract}

Keywords: cervical cancer; immunotherapy; immune checkpoint inhibitor

\section{Introduction}

Cervical cancer is the fourth most common cancer in women, and the seventh most common of all human cancers. The global incidence of and mortality from cervical cancer in 2012 were approximately 528,000 and 266,000, respectively, according to the Agency for Research on Cancer (IARC) database [1]. Currently, the first-line treatment of early-stage to established cervical cancer, including intraepithelial cancer, is surgery. Radiotherapy and chemotherapy have been used to treat patients with advanced uterine cervical cancer [2], but with limited success. In the GOG204 study, the overall survival (OS) extended from 13 months to 17 months in recurrent and unresectable cervical cancer with the addition of bevacizumab to platinum-based chemotherapy [3]. However, because treatment regimens for second-line and beyond have yet to be established, new methods need to be developed.

Cancer immunotherapy is a general term for treatments that strengthen or trigger the patient's own immune system to elicit anti-tumor effects. Cancer immunotherapy has a long history, starting with peptide vaccination and adoptive immunotherapy for cancer, though it did not show promising outcomes. However, with the recent introduction of immune checkpoint inhibitors that release the brakes of immune suppression, the evidence for immunotherapy in cancer treatment has finally become established. Clinical trials of immune checkpoint inhibitors have also been conducted in many areas, including cervical cancer. In particular, the programmed death-1(PD-1)/PD-1 ligand (PD-L1) inhibitor is highly effective in solid tumors, including cervical cancer, and has been approved by the Food and Drug Administration (FDA). This review describes the clinical studies of cancer immunotherapy to treat cervical cancer. 


\section{Immunotherapy Targeting HPV Related Gene in Cervical Cancer}

High-risk HPV is essential for carcinogenesis and maintaining cancer characteristics for cervical cancer, and immunotherapy targeting HPV has been expected. The E6 and E7 viral proteins, critical in driving HPV oncogenesis and foreign to the human immune system, represent ideal targets for therapeutic cancer vaccination [4]. Many clinical trials of vaccine monotherapy have been conducted. However, the effectiveness of vaccine monotherapy has not been proven for advanced cervical cancer [4]. Clinical trials of vaccine monotherapy have been conducted against CIN3 rather than advanced cervical cancer [4]. In recent years, the development of adjuvants has progressed. Clinical trials of a combination therapy of vaccines for advanced cervical cancer such as ADXS11-001 and ISA101 have been conducted. ADXS11-001 is a live, irreversibly attenuated Listeria monocytogenes (Lm)-listeriolysin O (LLO) immunotherapy bioengineered to secrete an antigen-adjuvant fusion protein consisting of a truncated, nonhemolytic fragment of LLO fused to human HPV-16 E7 (tLLO-HPV-16 E7) [5]. Phase II study evaluated the safety and efficacy of ADXS11-001, administered with or without cisplatin, in patients with recurrent/refractory cervical cancer following prior chemotherapy and/or radiotherapy. This study showed a 12-month OS rate of approximately 35\% (38 of 109 participants), as well as a median OS of 8.28 months in the axalimogene filolisbac monotherapy arm and 8.78 months in the combination arm [5]. Based on these results, a phase III study is currently planned for advanced cervical cancer (NCT02853604). ISA101 is among the most promising vaccines targeted to E6 and E7, and it consists of nine overlapping long E6 peptides and four overlapping 35-mer E7 peptides (synthetic long peptide HPV-16 vaccine), covering the complete sequence of the HPV-16 E6 and E7 oncoproteins. These long peptides effectively deliver antigens to dendritic cells, which then induce CD4+ and CD8+ T-cell responses by the HLA classes I and II presentation of the HPV-16 E6 and E7 processed epitope peptides [6]. Phase II study of combining Nivolumab and ISA101 for patients with incurable HPV 16-related cancer was conducted (NCT02426892). Twenty-four patients (cervical cancer: 1 patient) participated, and the overall response rate (ORR) was 33\%, median progression-free survival (PFS) was 2.7 months, and median overall survival (OS) was 17.5 months. However, Grade 3 to 4 adverse events occurred in 2 patients [6]. Randomized clinical trials are needed to confirm this result.

\section{Theoretical Basis for Checkpoint Inhibitors in Cervical Cancer}

The immunopathology of cancer varies. Cancer types in which the main effectors are $\mathrm{CD} 8^{+} \mathrm{T}$ cells specific to anti-tumor antigens (i.e., neoantigens) can be divided into "T cell inflamed," where anti-tumor $\mathrm{T}$ cells are aggregated before treatment, and "non-T cell inflamed," where such aggregation is absent. In T cell inflamed cancer, cytokines such as interferon (IFN)- $\gamma$, which are secreted by tumor antigen-specific $\mathrm{T}$ cells that recognize cancer cells, induce cancer cells and surrounding macrophages to express PD-L1, thereby suppressing CD8 ${ }^{+} \mathrm{T}$ cells and cancer elimination [7]. Such pathology is thought to be present in a percentage of cervical cancers that develop through human papilloma virus (HPV) infection, indicating that drugs that block this PD-1/PD-L1 pathway would be beneficial [8].

Sustained infection by HPV is profoundly related to the carcinogenesis of cervical cancer. Researchers have conducted mechanistic analyses of the relationship between HPV status and PD-L1 expression in HPV-related solid tumors, primarily in head and neck squamous cell carcinoma (SCC) and cervical cancer. In HPV-related head and neck SCC, PD-L1 expression on the cell membrane and IFN- $\gamma$ mRNA upregulation were observed. This result indicated that IFN- $\gamma$ was secreted through initial HPV infection, and subsequently induced PD-L1 expression [9]. Moreover, PD-L1 DNA methylation was negatively correlated with PD-L1 mRNA expression and was significantly associated with HPV infection in The Cancer Genome Atlas (TCGA) cohorts, indicating that PD-L1 DNA methylation is associated with transcriptional silencing and HPV infection in head and neck SCC [10]. Several teams that examined whether HPV infection affects PD-L1 expression in cervical cancer found that being HPV-positive is positively correlated with increased PD-L1 expression [11,12].

PD-L1 is expressed on the surface of cervical cancer tumor cells, antigen presenting cells, and tumor-infiltrating lymphocytes (TILs), whereas most PD-1-positive cells have been identified as T cells 
in the stroma of cervical cancer. PD-1 expression in the tumor stroma in cervical cancer is observed in $60.82 \%$ (59/97) of patients, according to one study [13], and in $46.97 \%$ (31/66) according to another study [14]. Many researchers have also examined PD-L1 expression in cervical cancer tissue. PD-L1 expression is observed in 34.4-96\% of cervical cancer tissues, but it is rarely observed in histologically normal cervical tissue $[15,16]$. An analysis by histology type reported that PD-L1 expression is observed in $80 \%$ of cervical SCC [12]. According to the TCGA database, PD-L1 amplification or acquisition was observed in 22\% (28/129) of patients with cervical SCC [17]. Furthermore, PD-L1 can be expressed on TILs, and this plays a role in the anti-tumor response blockade. According to a study of cervical SCC samples, the PD-L1 expression rates in cancer cells and TILs were $59.1 \%$ and $47.0 \%$, respectively [14]. These data suggest that both PD-L1 and PD-1 are widely expressed in cervical cancer tumor cells and stroma, indicating they could be a treatment target of a PD-1/PD-L1 inhibitor. To date, several lines of evidence support the possibility of using specific biomarkers to identify early stage cervical cancer and, in this way, offer a better prognosis for the patients $[18,19]$. Some biomarkers were analyzed in the carcinoma in situ (CIS), microinvasive, and squamous cell carcinoma (SCC) of the uterine cervix. There was a highly significant increase in PDL1 expression and decrease in Ki-67 (each $p<0.001$ ) in microinvasive cancer compared to CIS, whereas p16 and E6/E7 remained stable. As the lesion progressed to SCC, p16 and E6/E7 RNA remained strongly overexpressed with a concomitant over expression of importin- $\beta$ and Ki67 [19]. These data suggest that PD-L1 may be a useful biomarker to differentiate CIS from microinvasive cancer and, thus, anti-PD-L1 therapy may inhibit the progression of CIS to the invasive stage.

Cytotoxic T-lymphocyte antigen 4 (CTLA-4) is expressed on the T cell surface and, by binding to the B7 molecule expressed on the dendritic cells, it terminates T cell activity, thereby suppressing an excessive $\mathrm{T}$ cell immune response. CTLA- 4 is constantly expressed on regulatory $\mathrm{T}$ cells (Tregs). As seen when analyzing the Treg frequency in tumors of cervical cancer, patients with high Treg frequency have significantly shorter OS than patients with low Treg frequency [20], indicating that an anti-CTLA- 4 antibody could be a treatment target.

\section{Clinical Research Examining Checkpoint Inhibitors for Cervical Cancer}

Since 2015, clinical trials on various checkpoint inhibitors have been conducted for cervical cancer.

\subsection{PD-1/PD-l1 Inhibitor}

KEYNOTE-028 (phase Ib study) and KEYNOTE-158 (phase II study), which investigated pembrolizumab in recurrent and unresectable cervical cancers, were conducted. In KEYNOTE-028, pembrolizumab $10 \mathrm{mg} / \mathrm{kg}$ was given every 2 weeks. Twenty-four patients participated, and the overall response rate (ORR) was 17\%, 6-month progression-free survival (PFS) was 13\%, and 6-month OS was $66.7 \%$. Moreover, Grade 4 adverse events were not observed [21]. Based on these results, KEYNOTE-158 was conducted. In KEYNOTE-158, pembrolizumab 200 mg/kg was given every 3 weeks. The ORR was $12.2 \%$. Clinical response was observed only in PD-L1 positive cases. The drug effects were dependent of PD-L1 expression in this population [22]. Based on these results, the FDA approved pembrolizumab with PD-L1 IHC 22C3 PharmDx as a companion diagnostic in recurrent and unresectable advanced cervical cancer in June 2018. Moreover, CheckMate 358 (phase I-II study) using nivolumab was conducted. In this trial, nivolumab $240 \mathrm{mg} / \mathrm{kg}$ was given every 2 weeks in virus-related tumors, including cervical cancer. The ORR was $26.3 \%$, and the disease control rate was $70.8 \%$. For adverse events, Grade 3/4 hyponatremia and diarrhea were observed [23]. Based on the results of these studies, pembrolizumab and nivolumab appeared useful in recurrent and unresectable advanced cervical cancers, though a longer observation period is necessary in the future. (Table 1)

\subsection{Currently Ongoing Clinical Trials}

Previously conducted studies on immune checkpoint inhibitors in cervical cancer involved a monotherapy approach. (Table 2) Ongoing or planned immune checkpoint inhibitor studies in cervical 
cancer consist of combination therapy, aiming to achieve a greater response rate. Specifically, these studies investigate a combination with existing methods (radiation therapy or chemotherapy) or combination therapy with other molecularly targeted drugs.

Of these methods, the combination of radiation therapy and immune checkpoint inhibitors has been attracting attention. (Table 3) Concurrent chemoradiation therapy (CCRT) is the standard for treating locally advanced cervical cancer. The activation of anti-tumor immunity through radiation therapy is called the "abscopal effect." It is the phenomenon in which the anti-tumor immunity is activated through local radiation therapy, and distant metastatic lesions subsequently shrink or disappear. Until recently, the detailed mechanism for this effect was unknown. Recent studies showed that tumor cells impaired or destroyed by radiation therapy secrete new tumor antigens, and intracellular nuclear factor $\kappa \beta$ is activated due to DNA damage, resulting in IFN secretion. These activate the antigen-presenting cells, leading to the activation of anti-tumor immunity [24]. In unresectable lung cancer, the combination of CCRT and an immune checkpoint inhibitor was investigated, demonstrating positive effects [25]. In a phase III trial that treated patients with durvalumab after CCRT, the median PFS was 17.2 months, which was significantly longer than placebo at 5.6 months [26]. Based on these findings, the FDA approved durvalumab in unresectable lung cancer. However, no conclusions have been reached about the timing of this drug, or whether it is better as a combination or as maintenance therapy [25]. Based on this, clinical trials have been initiated in cervical cancer patients receiving CCRT.

Some ongoing trials are testing the addition of immune checkpoint inhibitors to systemic chemotherapy (paclitaxel/carboplatin or cisplatin with bevacizumab) in unresectable or recurrent advanced cervical cancer. (Tables 4-6).

\section{Development of Novel Immunotherapy}

\subsection{Genetically Modified T Cell Transfer Therapies}

In this method, antigen-specific receptors are artificially expressed on the $\mathrm{T}$ cell surface. These $\mathrm{T}$ cells are cultured in large numbers outside the body and subsequently re-infused into the patient's body. This method uses chimeric antigen receptors and T cell receptors [27]. Currently, the National Cancer Institute and collaborators are conducting a phase I/II trial in cervical cancer patients; with the conclusion of enrollment in December 2018, we are awaiting the results from this study (NCT01583686).

\subsection{Oncolytic Virotherapy}

Oncolytic virotherapy, which uses the virus' natural cytotoxic effects and immunostimulatory potential, has been attracting attention. This is a general term for treatment methods that use a virus that is cytotoxic against tumor cells and that is equipped with the capability to specifically infect cancer cells and use their machinery for proliferation. The virus itself generally exhibits cytotoxicity by infecting and proliferating in specific cells; oncolytic virotherapy uses viruses that possess the ability to more efficiently act on tumor cells or artificial viruses equipped with such characteristics through genetic modification techniques [28]. Up to the present time, researchers have conducted clinical trials using various viruses such as the herpes virus, adenovirus, and measles virus. Viral therapy not only directly exhibits anti-tumor effects, but also stimulates the immune system of the cancer patient to trigger an anti-tumor effect and is, therefore, considered to be one type of immunotherapy [29]. In patients with advanced and recurrent malignant melanoma, IMLYGIC ${ }^{\mathrm{TM}}$ (Amgen Inc., Thousand Oaks, CA, USA), a genetically modified herpes virus, led to favorable outcomes in a phase III trial, resulting in FDA approval [30]. In cervical cancer, the development of viral therapies using the herpes virus is currently underway [31,32]. Although the clinical effects are yet unknown, its application in cervical cancer treatment is expected in the future. 
Table 1. Clinical research outcomes of immunotherapy in cervical cancer

\begin{tabular}{|c|c|c|c|c|c|c|c|}
\hline Study & Authors & Study Population & $\mathbf{n}$ & Phase & Treatment & Response & Toxicity \\
\hline REGN2810 & $\begin{array}{l}\text { Papadopoulos et al., } \\
2016 \text { [33] }\end{array}$ & $\begin{array}{l}\text { Advanced solid } \\
\text { tumors }\end{array}$ & 58 & I & $\begin{array}{c}\text { Cemiplimab } \\
\text { monotherapy or } \\
\text { combination with hfRT }\end{array}$ & DCR $62.8 \%$ & $\begin{array}{l}\text { No dose-limiting } \\
\text { toxicities }\end{array}$ \\
\hline Keynote 028 & $\begin{array}{l}\text { Frenel et al., } \\
2017 \text { [22] }\end{array}$ & $\begin{array}{l}\text { Recurrent cervical } \\
\text { cancer with PD-L1 } \\
\text { positive tumors }\end{array}$ & 24 & IB & Pembrolizumab & $\begin{array}{c}\text { ORR } 17 \% \\
\text { Median duration of } \\
\text { response: } 19.3 \text { weeks } \\
\text { 6-month } \\
\text { PFS: } 21 \% \text {, OS: } 66.7 \%\end{array}$ & $\begin{array}{c}\text { Grade } 3 \mathrm{AE} \\
\text { Rash and proteinuria }\end{array}$ \\
\hline Keynote 158 & $\begin{array}{l}\text { Schellens et al., } \\
2017 \text { [23] }\end{array}$ & $\begin{array}{l}\text { Recurrent cervical } \\
\text { cancer }\end{array}$ & 46 & II & Pembrolizumab & $\begin{array}{c}\text { ORR } 12.2 \%(87 \% \\
\text { PD-L1+) } \\
\text { >27 weeks follow-up: } \\
\text { ORR: } 27 \%\end{array}$ & $\begin{array}{c}\text { Grade } 3 \mathrm{AE} \\
\text { AST/ALT elevation } \\
\text { and pyrexia }\end{array}$ \\
\hline \multirow[t]{2}{*}{ Checkmate 358} & $\begin{array}{l}\text { Hollebcque et al., } \\
2017 \text { [24] }\end{array}$ & $\begin{array}{l}\text { Recurrent or } \\
\text { metastatic } \\
\text { HPV-related } \\
\text { cancers }\end{array}$ & 19 & $\mathrm{I} / \mathrm{II}$ & Nivolumab & $\begin{array}{c}\text { ORR: } 26.3 \% \\
\text { DCR: } 70.8 \% \\
\text { Median PFS: } 5.5 \mathrm{mo} \text {, OS: } \\
\text { not reached }\end{array}$ & $\begin{array}{c}\text { Grade 3-4 AE } \\
\text { hyponatremia, } \\
\text { syncope and diarrhea }\end{array}$ \\
\hline & $\begin{array}{c}\text { Lheureux et al., } \\
2015[34]\end{array}$ & $\begin{array}{c}\text { Recurrent or } \\
\text { metastatic disease }\end{array}$ & 42 & $\mathrm{I} / \mathrm{II}$ & Ipilimumab & Median PFS: 2.5 mo & $\begin{array}{c}\text { Grade } 3 \mathrm{AE} \\
\text { Colitis and diarrhea }\end{array}$ \\
\hline GOG9929 & $\begin{array}{l}\text { Mayadev et al., } \\
\quad 2017 \text { [35] }\end{array}$ & $\begin{array}{l}\text { FIGO IB2/IIA or } \\
\text { IIB/IIIB/IVA, } \\
\text { positive nodes }\end{array}$ & 34 & I & CCRT with Ipilimumab & 1 year DFS: $74 \%$ & $\begin{array}{c}\text { Grade } 1-2 \mathrm{AE} \\
\text { Rash, Gastrointestinal } \\
\text { toxicity }\end{array}$ \\
\hline
\end{tabular}

DCR: disease control rate; ORR: objective response rate; PFS: progression-free survival; OS: overall survival rate; AE: adverse event; and DFS: disease-free survival. 
Table 2. Ongoing clinical trials of immunotherapy for cervical cancer (monotherapy).

\begin{tabular}{|c|c|c|c|c|c|c|c|}
\hline Clinical Trial Code & Title & Study Population & $\mathbf{n}$ & Phase & Treatment & Primary Outcomes & Secondary Outcomes \\
\hline NCT02257528 & $\begin{array}{c}\text { Nivolumab in Treating } \\
\text { Patients with Persistent, } \\
\text { Recurrent, or Metastatic } \\
\text { Cervical Cancer } \\
\text { (NRG-GYO-02) [36] }\end{array}$ & $\begin{array}{c}\text { Recurrent or } \\
\text { metastatic cervical } \\
\text { cancer }\end{array}$ & 25 & II & Nivolumab & ORR & PFS, OS \\
\hline NCT03257267 & $\begin{array}{c}\text { Study of REGN2810 in Adults } \\
\text { with Cervical Cancer (GOG } \\
\text { 3016/ENGOT-cx9) } \\
\text { (EMPOWER-Cervical) [37] }\end{array}$ & $\begin{array}{l}\text { Recurrent or } \\
\text { metastatic } \\
\text { platinum-refractory } \\
\text { cervical cancer }\end{array}$ & 436 & III & Cemiplimab & OS & PFS, ORR, DOR, QOL \\
\hline NCT03972722 & $\begin{array}{c}\text { Study of GLS-010 Injection in } \\
\text { Patients with Recurrent or } \\
\text { Metastatic Cervical Cancer } \\
{[38]}\end{array}$ & $\begin{array}{c}\text { Recurrent or } \\
\text { metastatic cervical } \\
\text { cancer }\end{array}$ & 89 & II & $\begin{array}{l}\text { GLS-010 (anti-PD1 } \\
\text { antibody) }\end{array}$ & ORR & PFS, DCR, DOR, OS \\
\hline NCT03104699 & $\begin{array}{c}\text { Phase } 1 / 2 \text { Study of AGEN2034 } \\
\text { in Advanced Tumors and } \\
\text { Cervical Cancer [39] }\end{array}$ & $\begin{array}{l}\text { Advanced cancer } \\
\text { Cervical cancer }\end{array}$ & 75 & $\mathrm{I} / \mathrm{II}$ & $\begin{array}{l}\text { AGEN2034 (anti-PD1 } \\
\text { antibody) }\end{array}$ & DLT, MTD & $\begin{array}{c}\text { Cmax, AUC, PFS, OS, } \\
\text { DOR }\end{array}$ \\
\hline NCT03808857 & $\begin{array}{c}\text { A Study in Recurrent or } \\
\text { Metastatic Cervical Cancer } \\
\text { Patients With PD-L1 Positive } \\
\text { Who Failed in Platinum-based } \\
\text { Chemotherapy [40] }\end{array}$ & $\begin{array}{l}\text { Recurrent or } \\
\text { metastatic cervical } \\
\text { cancer }\end{array}$ & 80 & II & $\begin{array}{l}\text { GB226 (anti-PD1 } \\
\text { antibody) }\end{array}$ & ORR & TTR, DCR, DOR, OS \\
\hline NCT03676959 & $\begin{array}{c}\text { A Clinical Study of PD-L1 } \\
\text { Antibody ZKAB001 (Drug } \\
\text { Code) in Recurrent or } \\
\text { Metastatic Cervical Cancer } \\
\text { [41] }\end{array}$ & $\begin{array}{l}\text { Recurrent or } \\
\text { metastatic cervical } \\
\text { cancer }\end{array}$ & 15 & I & ZKAB001 & DLT & MTD, ORR, AUC \\
\hline NCT01693783 & $\begin{array}{c}\text { Ipilimumab in Treating } \\
\text { Patients with Metastatic or } \\
\text { Recurrent Human Papilloma } \\
\text { Virus-Related Cervical Cancer } \\
\text { [42] }\end{array}$ & $\begin{array}{l}\text { Recurrent or } \\
\text { metastatic cervical } \\
\text { cancer }\end{array}$ & 44 & II & Ipilimumab & AE, ORR & \\
\hline
\end{tabular}

dose-limiting toxicity; MTD: maximum tolerated dose; Cmax: maximum plasma concentration; AUC: area under curve; and TTR: To time of response.
dimation 
Table 3. Ongoing clinical trials of immunotherapy for cervical cancer (combination with CCRT).

\begin{tabular}{|c|c|c|c|c|c|c|c|}
\hline Clinical Trial Code & Title & Study Population & $\mathrm{n}$ & Phase & Treatment & Primary Outcomes & Secondary Outcomes \\
\hline NCT03833479 & $\begin{array}{l}\text { TSR-042 as Maintenance Therapy } \\
\text { for Patients With High-risk } \\
\text { Locally Advanced Cervical } \\
\text { Cancer After Chemo-radiation } \\
\text { (ATOMICC) [43] }\end{array}$ & $\begin{array}{c}\text { Stage } \\
\text { IB/IIA/IIB/III/IVA } \\
\text { cervical cancer } \\
\text { with pelvic or } \\
\text { PALN } \\
\end{array}$ & 132 & II & $\begin{array}{c}\text { CRT } \\
\text { Maintenance TSR-042 } \\
\text { (anti-PD-1 antibody) }\end{array}$ & PFS & $\mathrm{AE}, \mathrm{OS}$ \\
\hline NCT03144466 & $\begin{array}{l}\text { A Study of Pembrolizumab And } \\
\text { Platinum With Radiotherapy in } \\
\text { Cervix Cancer (PAPAYA) [44] }\end{array}$ & $\begin{array}{l}\text { Recurrent or } \\
\text { metastatic } \\
\text { platinum-refractory } \\
\text { cervical cancer }\end{array}$ & 26 & I & $\begin{array}{c}\text { CRT with } \\
\text { pembrolizumab }\end{array}$ & MTD, Efficacy & PFS, OS \\
\hline NCT03298893 & $\begin{array}{l}\text { Nivolumab in Association With } \\
\text { Radiotherapy and Cisplatin in } \\
\text { Locally Advanced Cervical } \\
\text { Cancers Followed by Adjuvant } \\
\text { Nivolumab for up to 6 Months } \\
\text { (NiCOL) [45] }\end{array}$ & $\begin{array}{l}\text { Locally advanced } \\
\text { cervical cancer }\end{array}$ & 21 & I & CRT with nivolumab & DLT & DFS, AE, ORR, PFS \\
\hline NCT03738228 & $\begin{array}{l}\text { Atezolizumab Before and/or With } \\
\text { Chemoradiotherapy in Immune } \\
\text { System Activation in Patients } \\
\text { With Node Positive Stage IB2, II, } \\
\text { IIIB, or IVA Cervical Cancer [46] }\end{array}$ & $\begin{array}{c}\text { Stage IB/IIA } \\
\text { cervical cancer } \\
\text { with PALN or } \\
\text { IIB/III/IVA cervical } \\
\text { cancer with pelvic } \\
\text { or PALN }\end{array}$ & 40 & I & $\begin{array}{c}\text { Atezolizumab with CRT } \\
\text { Atezolizumab before } \\
\text { CRT }\end{array}$ & $\begin{array}{l}\text { Clonal expansion of } \mathrm{T} \text { cell } \\
\text { receptor beta }\end{array}$ & $\begin{array}{l}\text { Correlation of PD-L1 } \\
\text { expression, PFS, AE, } \\
\text { DLT }\end{array}$ \\
\hline NCT02635360 & $\begin{array}{l}\text { Pembrolizumab and } \\
\text { Chemoradiation Treatment for } \\
\text { Advanced Cervical Cancer [47] }\end{array}$ & $\begin{array}{l}\text { Locally advanced } \\
\text { cervical cancer }\end{array}$ & 88 & II & $\begin{array}{l}\text { Pembrolizumab with } \\
\text { CRT }\end{array}$ & $\begin{array}{l}\text { Change in immunologic } \\
\text { markers following } \\
\text { combination of study drug } \\
\text { with chemoradiation, DLT }\end{array}$ & $\begin{array}{c}\text { Metabolic Response } \\
\text { Rate on PET/CT } \\
\text { imaging, incidence of } \\
\text { distant metastases, } \\
\text { PFS, OS }\end{array}$ \\
\hline NCT03612791 & $\begin{array}{c}\text { Trial Assessing the Inhibitor of } \\
\text { Programmed Cell Death Ligand } 1 \\
\text { (PD-L1) Immune Checkpoint } \\
\text { Atezolizumab (ATEZOLACC) } \\
\text { [48] }\end{array}$ & $\begin{array}{l}\text { Locally advanced } \\
\text { cervical cancer }\end{array}$ & 190 & II & $\begin{array}{l}\text { Atezolizumab with CRT } \\
\text { and adjuvant } \\
\text { atezolizumab }\end{array}$ & PFS & \\
\hline NCT01711515 & $\begin{array}{c}\text { Chemoradiation Therapy and } \\
\text { Ipilimumab in Treating Patients } \\
\text { With Stages IB2-IIB or IIIB-IVA } \\
\text { Cervical Cancer [49] }\end{array}$ & $\begin{array}{l}\text { Locally advanced } \\
\text { cervical cancer }\end{array}$ & 34 & I & Ipilimumab with CRT & MTD, DLT & PFS \\
\hline
\end{tabular}


Table 4. Ongoing clinical trials of immunotherapy for cervical cancer (combination with chemotherapy).

\begin{tabular}{|c|c|c|c|c|c|c|c|}
\hline Clinical Trial Code & Title & Study Population & $\bar{n}$ & Phase & Treatment & Primary Outcomes & Secondary Outcomes \\
\hline NCT03912415 & $\begin{array}{l}\text { Efficacy and Safety of BCD-100 } \\
\text { (Anti-PD-1) in Combination With } \\
\text { Platinum-Based Chemotherapy } \\
\text { With and Without Bevacizumab as } \\
\text { First-Line Treatment of Subjects } \\
\text { With Advanced Cervical Cancer } \\
\text { (FERMATA) [50] }\end{array}$ & $\begin{array}{l}\text { Advanced cervical } \\
\text { cancer }\end{array}$ & 316 & III & $\begin{array}{l}\text { Paclitaxel + cisplatin } \\
\text { (or carboplatin) } \\
\text { Bevacizumab } \\
\text { BCD-100 (anti-PD-1) }\end{array}$ & OS & PFS, ORR, DOR \\
\hline NCT03912402 & $\begin{array}{l}\text { Efficacy and Safety of BCD-100 } \\
\text { (Anti-PD-1) in Combination With } \\
\text { Platinum-Based Chemotherapy } \\
\text { and Bevacizumab in Patients With } \\
\text { Recurrent, Persistent or Metastatic } \\
\text { Cervical Cancer (CAESURA) [51] }\end{array}$ & $\begin{array}{l}\text { Recurrent or } \\
\text { metastatic cervical } \\
\text { cancer }\end{array}$ & 49 & II & $\begin{array}{c}\text { Paclitaxel + Carboplatin } \\
\text { Bevacizumab } \\
\text { BCD-100 (anti-PD-1) }\end{array}$ & ORR & PFS, OS \\
\hline NCT03635567 & $\begin{array}{l}\text { Efficacy and Safety Study of } \\
\text { First-line Treatment With } \\
\text { Pembrolizumab (MK-3475) Plus } \\
\text { Chemotherapy Versus Placebo } \\
\text { Plus Chemotherapy in Women } \\
\text { With Persistent, Recurrent, or } \\
\text { Metastatic Cervical Cancer } \\
\text { (MK-3475-826/KEYNOTE-826) [52] }\end{array}$ & $\begin{array}{c}\text { Recurrent or } \\
\text { metastatic cervical } \\
\text { cancer }\end{array}$ & 600 & III & $\begin{array}{c}\text { Paclitaxel + cisplatin (or } \\
\text { carboplatin) } \\
\text { Bevacizumab } \\
\text { Pembrolizumab }\end{array}$ & PFS, OS & ORR, DCR, DOR \\
\hline NCT03228667 & $\begin{array}{l}\text { QUILT-3.055: A Study of ALT-803 } \\
\text { in Combination With PD-1/PD-L1 } \\
\text { Checkpoint Inhibitor in Patients } \\
\text { With Advanced Cancer [53] }\end{array}$ & Advanced cancer & 611 & II & $\begin{array}{l}\text { ALT-803 (IL-15 } \\
\text { superagonist) } \\
\text { Pembrolizumab } \\
\text { Nivolumab } \\
\text { Atezolizumab } \\
\text { Avelumab }\end{array}$ & ORR & PFS, OS, QOL \\
\hline NCT03556839 & $\begin{array}{c}\text { Platinum Chemotherapy Plus } \\
\text { Paclitaxel With Bevacizumab and } \\
\text { Atezolizumab in Metastatic } \\
\text { Carcinoma of the Cervix [54] }\end{array}$ & $\begin{array}{l}\text { Recurrent or } \\
\text { metastatic cervical } \\
\text { cancer }\end{array}$ & 404 & III & $\begin{array}{l}\text { Paclitaxel + cisplatin } \\
\text { Bevacizumab } \\
\text { Atezolizumab }\end{array}$ & OS & PFS, ORR, DOR, AE \\
\hline
\end{tabular}

OS: overall survival rate; PFS: progression-free survival; ORR: objective response rate; DOR: duration of response; DCR: disease control rate; QOL: quality of life; and AE: adverse event. 
Table 5. Ongoing clinical trials of immunotherapy for cervical cancer (combinations with checkpoint inhibitors).

\begin{tabular}{|c|c|c|c|c|c|c|c|}
\hline Clinical Trial Code & Title & Study Population & $\mathbf{n}$ & Phase & Treatment & Primary Outcomes & Secondary Outcomes \\
\hline NCT03894215 & $\begin{array}{c}\text { Phase } 2 \text { Study of Anti-PD-1 } \\
\text { Independently or in Combination } \\
\text { With Anti-CTLA-4 in Second-Line } \\
\text { Cervical Cancer [55] }\end{array}$ & $\begin{array}{l}\text { Recurrent cervical } \\
\text { cancer }\end{array}$ & 200 & II & $\begin{array}{l}\text { AGEN1884 (anti-PD-1) } \\
\text { AGEN2034 } \\
\text { (anti-CTLA4) }\end{array}$ & ORR & AE, DOR \\
\hline NCT03495882 & $\begin{array}{c}\text { Subjects With Metastatic or } \\
\text { Locally Advanced Solid Tumors, } \\
\text { and Expansion Into Select Solid } \\
\text { Tumors (Cervical) [56] }\end{array}$ & Cervical cancer & 60 & $\mathrm{I} / \mathrm{II}$ & $\begin{array}{l}\text { AGEN1884 (anti-PD-1) } \\
\text { AGEN2034 } \\
\text { (anti-CTLA4) }\end{array}$ & AE, DLT & ORR, DOR \\
\hline NCT03972722 & $\begin{array}{l}\text { Study of GLS-010 Injection in } \\
\text { Patients With Recurrent or } \\
\text { Metastatic Cervical Cancer [38] }\end{array}$ & $\begin{array}{l}\text { Recurrent or } \\
\text { metastatic cervical } \\
\text { cancer }\end{array}$ & 89 & II & $\begin{array}{l}\text { GLS-010 (anti-PD1 } \\
\text { antibody) }\end{array}$ & ORR & PFS, DCR, DOR, OS \\
\hline \multicolumn{8}{|c|}{$\begin{array}{l}\text { ORR: objective response rate; AE: adverse event; DOR: duration of response; DLT: dose-limiting toxicity; PFS: progression-free survival; DCR: disease control rate; and OS: overall } \\
\text { survival rate. }\end{array}$} \\
\hline Clinical Trial Code & Title & Study Population & $\mathbf{n}$ & Phase & Treatment & Primary Outcomes & Secondary Outcomes \\
\hline NCT03816553 & $\begin{array}{l}\text { SHR-1210 in Combination With } \\
\text { Apatinib in Patients With } \\
\text { Metastatic, Persistent, or } \\
\text { Recurrent Cervical Cancer [57] }\end{array}$ & $\begin{array}{l}\text { Recurrent or } \\
\text { metastatic cervical } \\
\text { cancer }\end{array}$ & 49 & II & $\begin{array}{c}\text { SHR-1210 } \\
\text { (anti-PD1 antibody) } \\
\text { Apatinib (TK inhibitor) }\end{array}$ & ORR & PFS, DCR, DOR, OS \\
\hline NCT02921269 & $\begin{array}{l}\text { Atezolizumab and Bevacizumab } \\
\text { in Treating Patients With } \\
\text { Recurrent, Persistent, or } \\
\text { Metastatic Cervical Cancer [58] }\end{array}$ & $\begin{array}{c}\text { Recurrent or } \\
\text { metastatic cervical } \\
\text { cancer }\end{array}$ & 22 & II & $\begin{array}{c}\text { Atezolizumab } \\
\text { Bevacizumab }\end{array}$ & Anti-tumor activity & OS, PFS, AE \\
\hline
\end{tabular}

ORR: objective response rate; PFS: progression-free survival; DCR: disease control rate; DOR: duration of response; OS: overall survival rate; and AE: adverse event. 


\section{Conclusions}

Cancer immunotherapy is finally playing its role as a new therapeutic option for multiple types of cancer, giving new hope to patients with recurrent cancer. Nonetheless, the evidence is still insufficient in cervical cancer. While waiting for the results of currently ongoing trials, it is also necessary to narrow down the patients who could be expected to have satisfactory effects using good biomarkers and to consider combination therapy with existing treatments. To understand and develop such therapy, further studies of the tumor immune microenvironment and immune-related genes through polymorphism analysis are needed.

Author Contributions: All authors contributed equally to this work and were involved at every stage in its development.

Funding: This research received no external funding.

Acknowledgments: The author thanks the Gynecologic Oncology Group, Department of Gynecology and Obstetrics, Iwate Medical University of school of medicine, for their academic support.

Conflicts of Interest: The authors declare no conflict of interest.

\section{References}

1. Cancer; IAfRo. Cancer Fact Sheets: Cervical Cancer. Available online: http:/gco.iarc.fr/today/data/pdf/factsheets/cancers/cancer-fact-sheets-16.pdf (accessed on 20 July 2019).

2. $\quad$ Koh, W.J.; Abu-Rustum, N.R.; Bean, S.; Bradley, K.; Campos, S.M.; Cho, K.R.; Chon, H.S.; Chu, C.; Clark, R.; Cohn, D.; et al. NCCN Guidelines Panel Disclosures Emily Wyse Patient Advocate NCCN Guidelines Version 2.2018 Cervical Cancer. Available online: https://www.nccn.org/professionals/physician_gls/pdf/cervical.pdf (accessed on 20 July 2019).

3. Tewari, K.S.; Sill, M.W.; Long, H.J.; Penson, R.T., III; Huang, H.; Ramondetta, L.M.; Landrum, L.M.; Oaknin, A.; Reid, T.J.; Leitao, M.M.; et al. Improved survival with bevacizumab in advanced cervical cancer. N. Engl. J. Med. 2014, 370, 734-743. [CrossRef]

4. Kawana, K.; Yasugi, T.; Taketani, Y. Human papillomavirus vaccines: Current issues \& future. Indian J. Med. Res. 2009, 130, 341-347. [PubMed]

5. Basu, P.; Mehta, A.; Jain, M.; Gupta, S.; Nagarkar, R.V.; John, S.; Petit, R. A Randomized Phase 2 Study of ADXS11-001 Listeria monocytogenes-Listeriolysin O Immunotherapy with or without Cisplatin in Treatment of Advanced Cervical Cancer. Int. J. Gynecol. Cancer 2018, 28, 764-772. [CrossRef] [PubMed]

6. Massarelli, E.; William, W.; Johnson, F.; Kies, M.; Ferrarotto, R.; Guo, M.; Feng, L.; Lee, J.J.; Tran, H.; Kim, Y.U.; et al. Combining Immune Checkpoint Blockade and Tumor-Specific Vaccine for Patients with Incurable Human Papillomavirus 16-Related Cancer: A Phase 2 Clinical Trial. JAMA Oncol. 2019, 5, 67-73. [CrossRef] [PubMed]

7. Jonathan, A.; Trujillo, R.F.; Sweis, R.B.; Jason, J.L. T Cell-Inflamed versus Non-T Cell-Inflamed Tumors: A Conceptual Framework for Cancer Immunotherapy Drug Development and Combination Therapy Selection. Cancer Immunol. Res. 2018, 6, 990-1000.

8. Cancer Genome Atlas Research Network; Albert Einstein College of Medicine; Analytical Biological Services; Barretos Cancer Hospital; Baylor College of Medicine; Beckman Research Institute of City of Hope; Buck Institute for Research on Aging; Canada's Michael Smith Genome Sciences Centre; Harvard Medical School; Helen, F. Graham Cancer Center \&Research Institute at Christiana Care Health Services; et al. Integrated genomic and molecular characterization of cervical cancer. Nature 2017, 543, 378-384.

9. Franzen, A.; Vogt, T.J; Müller, T.; Dietrich, J.; Schröck, A.; Golletz, C.; Brossart, P.; Bootz, F.; Landsberg, J.; Kristiansen, G.; et al. PD-L1 (CD274) and PD-L2 (PDCD1LG2) promoter methylation is associated with HPV infection and transcriptional repression in head and neck squamous cell carcinomas. Oncotarget 2018, 9, 641-650. [CrossRef] [PubMed]

10. Balermpas, P.; Martin, D.; Wieland, U.; Rave-Fränk, M.; Strebhardt, K.; Rödel, C.; Fokas, E.; Rödel, F. Human papilloma virus load and PD-1/PD-L1, CD8 ${ }^{+}$and FOXP3 in anal cancer patients treated with chemoradiotherapy: Rationale for immunotherapy. Oncoimmunology 2017, 6, e1288331. [CrossRef] [PubMed] 
11. Liu, C.; Lu, J.; Tian, H.; Du, W.; Zhao, L.; Feng, J.; Yuan, D.; Li, Z. Increased expression of PDL1 by the human papillomavirus 16 E7 oncoprotein inhibits anticancer immunity. Mol. Med. Rep. 2017, 15, 1063-1070. [CrossRef] [PubMed]

12. Mezache, L.; Paniccia, B.; Nyinawabera, A.; Nuovo, G.J. Enhanced expression of PD L1 in cervical intraepithelial neoplasia and cervical cancers. Mod. Pathol. 2015, 28, 1594-1602. [CrossRef]

13. Meng, Y.; Liang, H.; Hu, J.; Liu, S.; Hao, X.; Wong, M.S.K.; Li, X.; Hu, L. PD-L1 Expression Correlates with Tumor Infiltrating Lymphocytes and Response to Neoadjuvant Chemotherapy in Cervical Cancer. J. Cancer 2018, 9, 2938-2945. [CrossRef] [PubMed]

14. Feng, Y.C.; Ji, W.L.; Yue, N.; Huang, Y.C.; Ma, X.M. The relationship between the PD-1/PD-L1 pathway and DNA mismatch repair in cervical cancer and its clinical significance. Cancer Manag. Res. 2018, 10, 105-113. [CrossRef] [PubMed]

15. Enwere, E.K.; Kornaga, E.N.; Dean, M.; Koulis, T.A.; Phan, T.; Kalantarian, M.; Köbel, M.; Ghatage, P.; Magliocco, A.M.; Lees-Miller, S.P.; et al. Expression of PD-L1 and presence of CD8-positive T cells in pre-treatment specimens of locally advanced cervical cancer. Mod. Pathol. 2017, 30, 577-586. [CrossRef] [PubMed]

16. Reddy, O.L.; Shintaku, P.I.; Moatamed, N.A. Programmed death-ligand 1 (PD-L1) is expressed in a significant number of the uterine cervical carcinomas. Diagn. Pathol. 2017, 12, 45. [CrossRef] [PubMed]

17. Dijkstra, K.K.; Voabil, P.; Schumacher, T.N.; Voest, E.E. Genomics- and Transcriptomics-Based Patient Selection for Cancer Treatment with Immune Checkpoint Inhibitors: A Review. JAMA Oncol. 2016, 2, 1490-1495. [CrossRef]

18. Dijkstra, K.K.; Voabil, P.; Schumacher, T.N.; Voest, E.E. Tumor markers of uterine cervical cancer: A new scenario to guide surgical practice? Updates Surg. 2017, 69, 441-449.

19. Nicol, A.F.; De Andrade, C.V.; Gomes, S.C.; Brusadelli, M.G.; Lodin, H.M.; Wells, S.I.; Nuovo, G.J. The distribution of novel biomarkers in carcinoma-in-situ, microinvasive, and squamous cell carcinoma of the uterine cervix. Ann. Diagn. Pathol. 2019, 38, 115-122. [CrossRef] [PubMed]

20. Shang, B.; Liu, Y.; Jiang, S.J.; Liu, Y. Prognostic value of tumor-infiltrating FoxP3 ${ }^{+}$regulatory T cells in cancers: A systematic review and meta-analysis. Sci. Rep. 2015, 5, 15179. [CrossRef] [PubMed]

21. Frenel, J.S.; Le Tourneau, C.; O’Neil, B.; Ott, P.A.; Piha-Paul, S.A.; Gomez-Roca, C.; Van Brummelen, E.M.; Rugo, H.S.; Thomas, S.; Saraf, S.; et al. Safety and Efficacy of Pembrolizumab in Advanced, Programmed Death Ligand 1-Positive Cervical Cancer: Results From the Phase Ib KEYNOTE-028 Trial. J. Clin. Oncol. 2017, 35, 4035-4041. [CrossRef]

22. Schellens, J.H.M.; Marabelle, A.; Zeigenfuss, S.; Ding, J.; Pruitt, S.K.; Chung, H.C. Pembrolizumab for previously treated advanced cervical squamous cell cancer:preliminary results from the phase 2 KEYNOTE-158 study. J Clin Oncol. 2017, 35. [CrossRef]

23. Hollebecque, A.; Meyer, T.; Moore, K.N.; Machiels, J.P.; De Greve, J.; López-Picazo, J.M.; Oaknin, A.; Kerger, J.N.; Boni, V.; Evans, T.J.; et al. An open-label, multicohort, phase I/II study of nivolumab in patients with virus-associated tumors (CheckMate 358): Efficacy and safety in recurrent or metastatic (R/M) cervical, vaginal, and vulvar cancers. J. Clin. Oncol. 2017, 35. [CrossRef]

24. Rodriguez-Ruiz, M.E.; Vanpouille-Box, C.; Melero, I.; Formenti, S.C.; Demaria, S. Immunological Mechanisms Responsible for Radiation-Induced Abscopal Effect. Trends Immunol. 2018, 39, 644-655. [CrossRef] [PubMed]

25. McCall, N.S.; Dicker, A.P.; Lu, B. Beyond Concurrent Chemoradiation: The Emerging Role of PD-1/PD-L1 Inhibitors in Stage III Lung Cancer. Clin. Cancer Res. 2018, 24, 1271-1276. [CrossRef] [PubMed]

26. Antonia, S.J.; Villegas, A.; Daniel, D.; Vicente, D.; Murakami, S.; Hui, R.; Kurata, T.; Chiappori, A.; Lee, K.H.; De Wit, M.; et al. Overall Survival with Durvalumab after Chemoradiotherapy in Stage III NSCLC. N. Engl. J. Med. 2018, 379, 2342-2350. [CrossRef]

27. June, C.H.; Sadelain, M. Chimeric Antigen Receptor Therapy. N. Engl. J. Med. 2018, 379, 64-73. [CrossRef]

28. Fukuhara, H.; Ino, Y.; Todo, T. Oncolytic virus therapy: A new era of cancer treatment at dawn. Cancer Sci. 2016, 107, 1373-1379. [CrossRef] [PubMed]

29. Van Vloten, J.P.; Workenhe, S.T.; Wootton, S.K.; Mossman, K.L.; Bridle, B.W. Critical Interactions between Immunogenic Cancer Cell Death, Oncolytic Viruses, and the Immune System Define the Rational Design of Combination Immunotherapies. J. Immunol. 2018, 200, 450-458. [CrossRef] [PubMed] 
30. Andtbacka, R.H.; Kaufman, H.L.; Collichio, F.; Amatruda, T.; Senzer, N.; Chesney, J.; Delman, K.A.; Spitler, L.E.; Puzanov, I.; Agarwala, S.S.; et al. Talimogene Laherparepvec Improves Durable Response Rate in Patients with Advanced Melanoma. J. Clin. Oncol. 2015, 33, 2780-2788. [CrossRef] [PubMed]

31. Kagabu, M.; Yoshino, N.; Saito, T.; Miura, Y.; Takeshita, R.; Murakami, K.; Baba, T.; Sugiyama, T. The efficacy of oncolytic herpes simplex viral therapy for uterine cervical cancer in a mouse model. OncoTargets Ther. 2019. under review.

32. Kagabu, M.; Miura, Y.; Saito, T.; Takeshita, R.; Yoshino, N.; Sugiyama, T. Impact of new oncolytic herpes simplex virus vector armed with interleukine-12 for cervical cancer therapy. J. Clin. Oncol. 2014, 32. [CrossRef]

33. Papadopoulos, K.P.; Crittenden, M.R.; Johnson, M.L.; Lockhart, A.C.; Moore, K.N.; Falchook, G.S.; Formenti, S.; Carvajal, R.D.; Leidner, R.S.; Naing, A.; et al. A first-in-human study of REGN2810, a monoclonal, fully human antibody to programmed death-1 (PD-1), in combination with immunomodulators including hypofractionated radiotherapy (hfRT). J Clin Oncol. 2016, 34. [CrossRef]

34. Lheureux, S.; Butler, M.O.; Clarke, B.; Cristea, M.C.; Martin, L.P.; Tonkin, K.; Fleming, G.F.; Tinker, A.V.; Hirte, H.W.; Tsoref, D.; et al. Association of Ipilimumab With Safety and Antitumor Activity in Women With Metastatic or Recurrent Human Papillomavirus-Related Cervical Carcinoma. JAMA Oncol. 2018, 4, e173776. [CrossRef]

35. Mayadev, J.; Brady, W.E.; Lin, Y.G.; Da Silva, D.M.; Lankes, H.A.; Fracasso, P.M.; Ghamande, S.A.; Moore, K.N.; Pham, H.Q.; Wilkinson, K.J.; et al. A phase I study of sequential ipilimumab in the definitive treatment of node positive cervical cancer: GOG 9929. J. Clin. Oncol. 2017, 35. [CrossRef]

36. Nivolumab in Treating Patients With Persistent, Recurrent, or Metastatic Cervical Cancer. Available online: https:/clinicaltrials.gov/ct2/show/NCT02257528 (accessed on 20 July 2019).

37. Study of REGN2810 in Adults With Cervical Cancer. Available online: https:/clinicaltrials.gov/ct2/show/ NCT03257267 (accessed on 20 July 2019).

38. Study of GLS-010 Injection in Patients With Recurrent or Metastatic Cervical Cancer. Available online: https://clinicaltrials.gov/ct2/show/NCT03972722 (accessed on 20 July 2019).

39. Phase 1/2 Study of AGEN2034 in Advanced Tumors and Cervical Cancer. Available online: https:// clinicaltrials.gov/ct2/show/NCT03104699 (accessed on 20 July 2019).

40. A Study in Recurrent or Metastatic Cervical Cancer Patients With PD-L1 Positive Who Failed in Platinum-based Chemotherapy. Available online: https://clinicaltrials.gov/ct2/show/NCT03808857 (accessed on 20 July 2019).

41. A Clinical Study of PD-L1 Antibody ZKAB001 (Drug Code) in Recurrent or Metastatic Cervical Cancer. Available online: https://clinicaltrials.gov/ct2/show/NCT03808857 (accessed on 20 July 2019).

42. Ipilimumab in Treating Patients With Metastatic or Recurrent Human Papilloma Virus-Related Cervical Cancer. Available online: https://clinicaltrials.gov/ct2/show/NCT01693783 (accessed on 20 July 2019).

43. TSR-042 as Maintenance Therapy for Patients With High-risk Locally Advanced Cervical Cancer After Chemo-radiation (ATOMICC). Available online: https://clinicaltrials.gov/ct2/show/NCT03833479 (accessed on 20 July 2019).

44. A Study of Pembrolizumab And Platinum With Radiotherapy in Cervix Cancer (PAPAYA). Available online: https://clinicaltrials.gov/ct2/show/NCT03144466 (accessed on 20 July 2019).

45. Nivolumab in Association With Radiotherapy and Cisplatin in Locally Advanced Cervical Cancers Followed by Adjuvant Nivolumab for up to 6 Months (NiCOL). Available online: https://clinicaltrials.gov/ct2/show/ NCT03298893 (accessed on 20 July 2019).

46. Atezolizumab Before and/or With Chemoradiotherapy in Immune System Activation in Patients With Node Positive Stage IB2, II, IIIB, or IVA Cervical Cancer. Available online: https://clinicaltrials.gov/ct2/show/ NCT03738228 (accessed on 20 July 2019).

47. Pembrolizumab and Chemoradiation Treatment for Advanced Cervical Cancer. Available online: https: //clinicaltrials.gov/ct2/show/NCT02635360 (accessed on 20 July 2019).

48. Trial Assessing the Inhibitor of Programmed Cell Death Ligand 1 (PD-L1) Immune Checkpoint Atezolizumab (ATEZOLACC). Available online: https://clinicaltrials.gov/ct2/show/NCT03612791 (accessed on 20 July 2019).

49. Chemoradiation Therapy and Ipilimumab in Treating Patients With Stages IB2-IIB or IIIB-IVA Cervical Cancer. Available online: https://clinicaltrials.gov/ct2/show/NCT01711515 (accessed on 20 July 2019). 
50. Efficacy and Safety of BCD-100 (Anti-PD-1) in Combination With Platinum-Based Chemotherapy With and Without Bevacizumab as First-Line Treatment of Subjects With Advanced Cervical Cancer (FERMATA). Available online: https://clinicaltrials.gov/ct2/show/NCT03912415 (accessed on 20 July 2019).

51. Efficacy and Safety of BCD-100 (Anti-PD-1) in Combination With Platinum-Based Chemotherapy and Bevacizumab in Patients With Recurrent, Persistent or Metastatic Cervical Cancer (CAESURA). Available online: https://clinicaltrials.gov/ct2/show/NCT03912402 (accessed on 20 July 2019).

52. Efficacy and Safety Study of First-line Treatment With Pembrolizumab (MK-3475) Plus Chemotherapy Versus Placebo Plus Chemotherapy in Women With Persistent, Recurrent, or Metastatic Cervical Cancer (MK-3475-826/KEYNOTE-826). Available online: https:/clinicaltrials.gov/ct2/show/NCT03635567 (accessed on 20 July 2019).

53. QUILT-3.055: A Study of ALT-803 in Combination With PD-1/PD-L1 Checkpoint Inhibitor in Patients With Advanced Cancer. Available online: https://clinicaltrials.gov/ct2/show/NCT03228667 (accessed on 20 July 2019).

54. Platinum Chemotherapy Plus Paclitaxel With Bevacizumab and Atezolizumab in Metastatic Carcinoma of the Cervix. Available online: https://clinicaltrials.gov/ct2/show/NCT03556839 (accessed on 20 July 2019).

55. Phase 2 Study of Anti-PD-1 Independently or in Combination With Anti-CTLA-4 in Second-Line Cervical Cancer. Available online: https://clinicaltrials.gov/ct2/show/NCT03894215 (accessed on 20 July 2019).

56. Subjects With Metastatic or Locally Advanced Solid Tumors, and Expansion Into Select Solid Tumors (Cervical). Available online: https://clinicaltrials.gov/ct2/show/NCT03495882 (accessed on 20 July 2019).

57. SHR-1210 in Combination With Apatinib in Patients With Metastatic, Persistent, or Recurrent Cervical Cancer. Available online: https://clinicaltrials.gov/ct2/show/NCT03816553 (accessed on 20 July 2019).

58. Atezolizumab and Bevacizumab in Treating Patients With Recurrent, Persistent, or Metastatic Cervical Cancer. Available online: https://clinicaltrials.gov/ct2/show/NCT02921269 (accessed on 20 July 2019).

(C) 2019 by the authors. Licensee MDPI, Basel, Switzerland. This article is an open access article distributed under the terms and conditions of the Creative Commons Attribution (CC BY) license (http://creativecommons.org/licenses/by/4.0/). 